\title{
Aldibereko teknika biologikoen bitartezko lurzoru kutsatuen erremediazioa
}

\author{
(Simultaneous combination of biological strategies for the \\ remediation of contaminated soils)
}

\author{
Erik Urionabarrenetxea ${ }^{1}$, Nerea Garcia-Velasco ${ }^{1}$, Mikel Anza ${ }^{2}$, Unai Artetxe ${ }^{3}$, \\ Rafael Lacalle ${ }^{3}$, Carlos Garbisu' ${ }^{2}$, Txema Becerril ${ }^{3}$, Manu Soto $^{* 1}$ \\ ${ }^{1}$ Zelulen Biologia Ingurumen Toxikologian (ZBIT) ikerketa-taldea, Zoologia \\ eta Animalia Zelulen Biologia Saila, Zientzia eta Teknologia Fakultatea \\ eta Plentziako Itsas Estazioa (PiE-UPV/EHU) \\ ${ }^{2}$ NEIKER - Nekazal Ikerketa eta Garapenerako Euskal Institutua, Euskal Ikerketa \\ eta Teknologia Aliantza (BRTA) \\ ${ }^{3}$ Ecofisko ikerketa-taldea. Landareen Biologia eta Ekologia Saila, \\ (UPV/EHU), Leioa, Bizkaia
}

LABURPENA: Gaur egun ugariak dira mundu mailan zein Euskal Herrian jarduera antropikoek kutsatuta dauden edo kutsatuta egon daitezkeen lurrak. Metal astun edo elementu organikoekin kutsatuta dauden lurzoru horiek erremediatzeko teknikak anitzak eta izaera ezberdinekoak dira. Alde batetik, erremediazio-teknika fisiko-kimiko klasikoak daude, errendimendu altu eta aplikazio-denbora laburrak dituztenak, baina, kontrara, kostu altu eta inpaktu ekologiko handiak dituztenak. Bestetik, teknika biologikoak daude, merkeagoak eta ingurumenarekiko adeitsuagoak, baina, aplikazio-denbora luzeak behar dituztenak. Horien artean daude landareekin gauzatzen den fitoerremediazioa, zizareekin gauzatzen den bermierremediazioa zein mikrobioekin gauzatzen den bioerremediazioa. Lan honetan, teknika horien ezaugarri nagusiak eta aplikagarritasuna jorratzen dira, bakarkako erremediazio-teknika zein teknika konbinatu gisa.

HITZ GAKOAK: lurzoruak, kutsadura, bioerremediazioa, fitoerremediazioa, bermierremediazioa.

\begin{abstract}
Anthropogenic activities led to the proliferation of polluted sites or potentially polluted sites around the world; including Basque Country. Technologies to remediate or clean these soils, mainly polluted by heavy metals or organic pollutants are diverse and of different nature. On the one hand, classic physico-chemical remediation techniques can be found; with high yields and short application times; but, high costs and high ecological impacts. On the other hand, biological techniques could be found. These technologies are cheaper and more environmental-friendly; but, they require long application times. Among most used bioremediation technologies plant-based phytoremediation, worm based vermiremediation, and mibrobia based bioremediation (or bioaugmentation) can be found. This paper deals with the main features of these techniques and their applicability; both as single remediadion techniques or combined.
\end{abstract}

KEYWORDS: soils, pollution, bioremediation, phytoremediation, vermiremediation.

\footnotetext{
* Harremanetan jartzeko / Corresponding author: Manu Soto. Zelulen Biologia Ingurumen Toxikologian (ZBIT) ikerketa-taldea, Zoologia eta Animalia Zelulen Biologia Saila, Zientzia eta Teknologia Fakultatea eta Plentziako Itsas Estazioa (PiE-UPV/EHU), Leioa, Bizkaia. - manu.soto@ehu.eus - https://orcid.org/0000-0002-4541-8182

Nola aipatu / How to cite: Urionabarrenetxea, Erik; Garcia-Velasco, Nerea; Anza, Mikel; Artetxe, Unai; Lacalle, Rafael; Garbisu, Carlos; Becerril, Txema; Soto, Manu (2021). «Aldibereko teknika biologikoen bitartezko lurzoru kutsatuen erremediazioa". Ekaia, 40, 2021, 157-180. (https://doi.org/10.1387/ekaia.22319).
}

Jasotze-data: 2020, abenduak 4; Onartze-data: 2021, otsailak 12.

ISSN 0214-9753 - eISSN 2444-3581 / (c) 2021 UPV/EHU

cc)()ㅇ Lan hau Creative Commons Aitortu-EzKomertziala-LanEratorririkGabe 4.0 Nazioartekoa 
Erik Urionabarrenetxea, Nerea Garcia-Velasco, Mikel Anza, Unai Artetxe, Rafael Lacalle, Carlos Garbisu, Txema Becerril, Manu Soto

\section{SARRERA}

Lurzorua kutsa dezaketen elementu kimiko ugarienen artean daude metalak (Cd, $\mathrm{Cr}, \mathrm{Cu}, \mathrm{Hg}, \mathrm{Mn}, \mathrm{Ni}, \mathrm{Pb}, \mathrm{V}$, eta $\mathrm{Zn}$ ), metaloideak (As, Bo, eta $\mathrm{Sb}$ ), halogenatuak (F eta I), ez-metalak (Se) eta aktinoideak (U) [1, 3]. Metal astunekin kutsatutako lurzoruen arazoa mundu mailako arazo bilakatu da beren iraunkortasunagatik eta natura ez-degradagarriagatik [3]. Izan ere, ezaugarri horrek maila toxikoak izatera arte metatzea ahalbidetu izan du. Metal astunak hainbat bidetatik hel daitezke lurzoruetara; hala nola, pestizidak eta ongarriak erabiltzean, produktu kimikoak sortzean, industria-hondakinetatik, meategietatik, hondakin-uren isuritik; hots, jarduera antropogenikoetatik [3-4]. Behin lurrean, bertako materia organikora atxikitzen dira, eta metalaren mugikortasuna eta bioeskuragarritasuna murriztu egiten da. Edonola ere, lotura horiek ekosistementzako funtsezko prozesuak gauzatzen diren ataletan gertatzen dira; deskonposizioa eta nutrienteen mineralizazioa eragiten dute, eta ekosistemen funtzionamendua erasan [5]. Metal batzuk beharrezko traza-elementuak diren arren, maila eta denbora jakin batzuen gaineko metalen esposizioak efektu toxikoak eragin ditzake lurzoruko organismoengan, eta horien ugaritasuna, dibertsitatea eta antolamendua kaltetu [6].

Lurzorua kutsa dezaketen konposatu organikoen taldean, aldiz, egituran karbonoa (talde funtzionalekin ala ez) daukaten konposatuak batzen dira; hala nola, pestizidak, hidrokarburoak, PAHak, PCBak, PBBak, PBDEak, PCDFak, PCDDak, farmazia-produktuak edo surfaktanteak. Nekazaritza-jarduera areagotzeak pestiziden erabilera emendatzea ekarri du; gaur egun, 400 substantzien edo pestiziden erabilera dago onartua Europako nekazaritza-lurretan [7]. Hala ere, argitaratutako ekotoxikologiako ikerketa gehienak metalen toxikologian ardaztu dira [8], eta gutxiago ikertu dira pestiziden efektuak [7]. Gainera, ikertutako pestizida horiek Europan erabiltzea debekatuta dauden pestizidak izaten dira gehienbat; hala nola, paraquat-a (1,1'-dimetil-4,4'-bipiridilo dikloruroa), dikloropropenoa (1,3-dikloropropenoa) edo cianamida. Metalak ez bezala, pestizidak eta PAHak lurzoruan erraz degradatzen diren konposatuak dira [9]. Lurzoruan dauden kutsatzaileen degradazioa, bioeskuragarritasuna eta toxikotasuna erlazionatuta daude lurzoruaren $\mathrm{pH}-\mathrm{a}, \mathrm{MO}$ kantitatea eta antzeko propietateekin.

Konposatu/elementu kimiko horiek isurtzen direnean edo eremu ezberdinetara heltzen direnean, ingurumena degrada dezakete, eta ekosistemen eta gizakiaren osasuna kaltetu. Hori dela eta, beharrezkoa da lurzoruan dauden konposatuen kontzentrazioak eta horiek sor ditzaketen arrisku potentzialak ikertzea, lurzoruaren sailkapen eta kudeaketa egokia egiteko. 


\section{LURZORUEN KUTSADURA EAE-N}

Lurzoru baten egoera ikertzeko osasun-ikuspegia gomendagarriagoa eta integralagoa den arren, gutxi dira oraindik ekotoxikologia-testak legedian barneratu dituzten herrialdeak. Analisi kimikoez baliatuta lurzoru bat kutsatuta dagoela onartu eta adierazten denean - hots, lurzoruaren kalitatearen adierazpena argitaratzen denean -, neurri edo aukera ezberdinak plantea daitezke jokalekuaren arabera. Eusko Jaurlaritzako (EJ) Ingurumen Sailburuordetzaren arabera, lurzoru baten kalitatea bere afekzioaren araberakoa izango da, eta hiru kategoria hauen artean egon daiteke:

- Eraldatu gabeko lurzorua. Kutsagarria izan litekeen jarduera bat jasan duen baina bere kalitatean aldaketarik pairatu ez duen lurzorua.

- Eraldatutako lurzorua. Lurzoru mota honetan, erreferentziazko balio adierazleak gainditzen dituzten substantzia-kontzentrazioak identifikatzen dira, baina lurzorua ez da lurzoru kutsatutzat jotzen, ez duelako arriskurik sortzen ez giza osasunerako eta ezta ekosistemetarako ere.

Erreferentzia-balioak eta kontzentrazio-balioak erkatze aldera, Eusko Jaurlaritzak Ebaluaziorako Balio Adierazleak (EBA) argitaratu zituen otsailaren 4ko 1/2005 Legean, lurzorua ez kutsatzeko eta kutsatutakoa garbitzeari buruzkoan (ondoren ekainaren 25eko 4/2015 Legeak ordeztua). Horren arabera, hiru maila ezartzen dira erasandako lurrak sailkatzeko: EBA-A maila (substantzia jakin batek EAEko lurzoruetan era naturalean dagoenean duen kontzentrazio -tartearen maila gorenarekin bat datorren estandarra), EBA-B maila (lurzoruaren erabilera desberdinen arabera definitzen den estandarra, arriskuaren onargarritasun-atalase baxuena ezartzen duena) eta EBA-C maila (gehienezko arrisku onargarria, edo arriskuaren onargarritasun-atalase altuena).

- Lurzoru kutsatua. Gizakiaren jardueren eraginez, ezaugarri kimikoak eraldatuta dauzkan lurzoru mota. Pertsonen edo/eta ekosistemen osasunarentzat duen arriskuagatik, bateraezina da egungo erabilerarekin edo aurreikusitakoarekin.

Eusko Jaurlaritzak erabiltzen duen irizpide horren arabera, kutsadura kontzeptua arriskuarekin loturiko kontzeptua da; hau da, kutsadura afekzio kimikoaren eta arriskuaren (erabilera jakin batean elementu kimikoa hartzaile batekin kontaktuan jartzerakoan, pertsonen osasunean edo ingurumenaren osasunean ondorio kaltegarriak izateko probabilitatea) arteko elkarrekintzatik sortzen da.

Kutsatutako lurzoruetarako hainbat kudeaketa-aukera daude. Horrela, kasurik txarrenean, lur-esparrua itxi egin beharko litzateke, bertara sar litekeen edozein erabiltzaileren osasuna babesteko xedez. Beste aukera 
Erik Urionabarrenetxea, Nerea Garcia-Velasco, Mikel Anza, Unai Artetxe, Rafael Lacalle, Carlos Garbisu, Txema Becerril, Manu Soto

bat litzateke lurzoru horren erabilera aldatzea, erabilera berrien bitartez, arriskutsuak izan litezkeen agertokiak edo elkarrekintzak murriztuz edo mugatuz. Hala ere, ekainaren 25eko 4/2015 Legeak, Lurzorua kutsatzea saihestu eta kutsatutakoa garbitzeari buruzkoak, kutsatutako eta eraldatutako lurrak berreskuratzearen beharrizana ezartzen du [3]. Legearen arabera, eraldatutako lurzoruak berreskuratzeko neurriek lurzorua jatorrizko egoerara bueltatzea izango dute helburu; egoera ezagutzea ezinezkoa izango balitz, teknologia onenak erabiliz, lurzoruaren kalitate-estandar batzuk lortzea izango litzateke helburua: «gutxienez EBA-B ebaluaziobalio adierazleen parekoak edo petrolioaren guztizko hidrokarburoen baliokideak (TPH) eta, hala dagokionean, urarentzat ezarritakoen parekoak» (4/2015 Legea, Lurzorua kutsatzea saihestu eta kutsatutakoa garbitzeari buruzkoa).

Lurzoru kutsatuak berreskuratzeko erremediazio-teknologiak dira kutsatzaileen toxikotasuna, bolumena edo mugikortasuna murriztuko duten prozesu fisiko-kimiko edota biologikoen multzoa [10-11]. Teknologia horien bitartez, lurzoru eta lurpeko ur kutsatzaileen mugikortasuna eragin dezaketen propietate fisiko eta kimikoak eraldatzea bilatzen da (gehienetan). Era berean, kutsatzaileen forma kimikoek eta lurzoruaren ezaugarriek zeharo baldintzatzen dute erremediazio-tratamenduaren aukeraketa. Lekuaren ezaugarri fisikoen eta kutsadura mailaren/motaren gaineko informazioa izatea beharrezkoa da eremuaren ebaluazio eta erremediazio egokia gauzatzeko. Horretarako, karakterizazio-emaitzak erregulazio-domeinu konkretu bateko kalitate estandarrekin konparatzen dira, edo lekuaren arrisku-azterketa espezifiko bat gauzatzen da. Karakterizazio-emaitzak erregulazio konkretu bateko kalitate estandarrak baino altuagoak direnean edo arrisku-ebaluazioa negatiboa denean, lurzoru horren erremediazioa gauzatzea da kudeaketa-aukeretako bat [3], lurzoru-baldintzak zein beronen funtzionalitatea berreskuratzea ahalbidetuz.

\section{LURZORU KUTSATUEN ERREMEDIAZIOA}

\subsection{Erremediazioa baldintzatu dezaketen lurzoruaren propietate kimikoak eta fisikoak}

Erremediazioaren abiadura eta bideragarritasuna lurzoruaren ezaugarriek baldintzatuta dago [12-13]. Ezaugarri baldintzatzaileen artean, anioi organikoen presentzia, $\mathrm{pH}-\mathrm{a}$, katioiak trukatzeko gaitasuna eta $\mathrm{MO}$ kantitatea dira azpimarragarrienak.

Lurzoruko uretan, anioi inorganikoen presentziak (karbonatoak, fosfatoak, sulfuroak) lurzoruen metalak (kimikoki) konplexatzeko ahalmena eragin dezake. Izan ere, anioi horiek konplexu disolbagaitzak sor ditzakete metal ioiekin, metalen desortzioa eta/edo prezipitazioa bultzatuz [14]. 
Lurzoruen $\mathbf{p H}$-a metalen disolbagarritasunean gehien eragiten duen faktorea da [15]. Lurzoruaren $\mathrm{pH}$ balioak 4 eta 8.5 barrutian izan ohi dira normalean; aluminioa izaten da indargetzailea $\mathrm{pH}$ baxuetan, eta karbonato kaltzikoa $\left(\mathrm{CaCO}_{3}\right) \mathrm{pH}$ altuetan [16]. Metal katioiak mugikorragoak dira baldintza azidikoetan ( $\mathrm{pH}$ baxuetan), eta, baldintza horietan, anioiek oxido metaletan absorbatzera egiten dute [14,17]; $\mathrm{pH}$ altuetan, aldiz, katioiak prezipitatu edo mineralen gainazalean adsorbatzen dira, eta anioiak mobilizatu egiten dira. Burdin, aluminio eta manganeso metal oxido hidratoek zeharo baldintzatu ditzakete lurzoru metal-kontzentrazioak [18]; izan ere, aldaketa ioniko, absortzio espezifiko eta gainazaleko prezipitazio bitartez, soluzioan dauden katioiak eta anioiak baztertu ditzakete [17, 19]. Hori guztia Katioiak Trukatzeko Gaitasunak (KTG, CEC-Cation Exchange Capacity) eta Anioiak Trukatzeko Gaitasunak (ATG, AEC-Anion Exchange Eapacity) baldintzatzen dute. Lehenak mineral-gainazal batean trukagai dauden katioi-kontzentrazioari egiten dio erreferentzia; askotan, lurzoruek katioiak (metalak, kasu) hartzeko duten gaitasuna edo afinitatea adierazteko erabili izan da. ATGk, aldiz, lurzoruak anioiak bereganatzeko duen gaitasunari egiten dio erreferentzia; orokorrean, KTG baino baxuagoa da. Lurzoruan ioi-trukaketarako ahalmen altua duten materialen artean, bereziki aipatzekoak dira goian aipatutako oxido hidratoak eta buztinak [20].

Lurzoruko MOa - pisu molekular altuko molekulak dauzkan eta deskonposaketarekiko erresistenteak diren konposatu koloidalen nahasturaz sortua dagoena [21] - hondar organikoen deskonposaketa biologiko eta kimiko bitartez sortzen da; bereizi egiten dira aldatu gabeko materiala eta eraldatutako produktua (humusa) [22]. MOak ezinbesteko papera jokatzen du lurzoru-funtzioen erregulazioan; besteak beste, gainazal-kargen ekarpenean (KTG) [14], hezetasunaren erregulazioan, elikagaien ziklazioan eta lurzoruaren egituraren mantenuan laguntzen du [22, 23]. Gainera, MOak, eta bereziki talde karboxiliko eta fenolikoak dituen material humikoak, positiboki kargatutako molekulak finkatzeko ahalmena dauka (katioi metalikoak kasu); eta, horrela, murriztu egiten da horien eskuragarritasuna eta mugikortasuna [24].

USDA (1987, Estatu Batuetako Nekazaritza Saila) lurzoru-taxonomia sailkapenaren arabera, lurzoru bateko partikulen tamainaren antolamendua hiru azpitalde handitan sailkatzen da: haretan (2 eta $0,05 \mathrm{~mm}$ bitartean), lohietan $(0,05$ eta $0,002 \mathrm{~mm}$ bitartean) eta buztinetan $(<0,002 \mathrm{~mm})$. Tamaina handi eta ertaineko materialek ( $2 \mathrm{~mm}$ baino handiagoak) lurzoruaren eskeletoa osatzen dute; tamaina txikiko materialek (lohi eta, batez ere, buztinek), aldiz, lurzoruko osagai mineralen tarte aktiboena osatzen dute. Partikula finenak $(<100 \mu \mathrm{m})$ erreaktiboagoak dira, batik bat, material lodiagoek baino azalera/gainazal espezifiko handiagoa izaten baitute [14]. Horrela, buztinean aberatsak diren lurzoruak kimikoki aktiboenak izaten dira [22, 25], partikula finenek hartzen baitituzte bizitzarako beharrezko elikagaiak/nutrienteak edo 
Erik Urionabarrenetxea, Nerea Garcia-Velasco, Mikel Anza, Unai Artetxe, Rafael Lacalle, Carlos Garbisu, Txema Becerril, Manu Soto

kutsaduraren parterik handiena. Gainera, antolamenduak, lurzoruaren egiturak, koloreak, porositateak, KTGak eta uraren erretentzio-gaitasunak (WHCWater Holding Capacity) baldintzatzen dute partikulen tamaina.

Hezetasuna ere kontuan hartzeko faktorea da, lurzoruen ahalmen kimikoan duen eraginagatik batik bat. Izan ere, lurzoruaren ur kantitateak disolbatutako mineral kantitatean, $\mathrm{pH}$-an eta erredox potentzialean eragiten du, eta, zeharka, kutsatzaileen egonkortasuna edo erreaktibotasuna bultzatzen du.

\subsection{Erremediazio-teknologia konbentzionalak}

Mende hasieran, kutsatutako lurren arazoa konpontzeko, kutsatutako lurra induskatu egiten zen, eta landa batean edo isolamenduan jarri, kutsadura-lekutik ateratzea eragozten zuen itxitura batean; horrela, inguruko lur-eremuak kutsatzea eragozten zuten [26]. Praktika horrek, arriskua maneiatzearen ikuspuntutik egokia zen arren, ez zion kutsadurari edo kutsadura-iturriari eraso egiten. Lur kutsatua zabor gisa kudeatzea litzateke, nolabait. Gaur egun, batez ere arautze-aldaketek bultzatuta (gero eta zorrotzagoak baitira), aldatzen ari da lurzoruen erremediazioaren gaineko paradigma, eta teknologia berri eta eraginkorragoak garatzen ari dira. Teknika horiek kutsatutako lurzoruan bertan aplika daitezke (in situ), edo kutsatutako eremutik atera eta horietatik urrun, ondoren jatorrizko eremura bueltatzeko (ex situ). Lehenengoak kutsatutako lurrean edo ingurukoetan gauzatzen ari diren ekintzak mantentzea ahalbidetzen du; bigarrenak, aldiz, baldintzak maneiatzea, kutsatzaileak barreiatzea eta efizientziaren optimizazioa ahalbidetzen du.

Deskontaminazio-teknikak, tratamenduaren izaeraren arabera, talde hauetan sailka daitezke: fisikoak (termikoak barne), kimikoak eta biologikoak, nagusiki [27]. Egoera batzuetan, tratamendu eraginkor eta merkeena lortze aldera, beharrezkoa izaten da teknika horien bi- edo multi-konbinazioak gauzatzea [26, 28, 29].

Tratamendu fisikoen artean daude teknologia termikoa (beiratzea, kasu) [30], solidifikazioa [31], lurrun-erauzketa, espaziazio aereoa (Air Sparging, ingelesez), garbiketa [32], elektroerremediazioa [33] edo partikulen sailkapena [26]. Kasu gehienetan, tratamendu horiek mugitu egiten dituzte kutsatzaileak lurzoru-ur konplexutik, eta, ondoren, tratatu edo «isuri» egiten dituzte. Kasu askotan, tratamendu fisikoek degradazio biologikoen eraginkortasuna emenda dezakete, edo, zeharka, kutsatzaileak suntsitzea eragin. Bestalde, kutsatzaileen deuseztatze hori lurzoruen izaerak baldintzatuko du zeharo (erremediazio fisikoa eraginkorragoa da lurzoru marduletan).

Tratamendu kimikoak lurrazpiko ur kutsatuak tratatzeko erabiltzen dira gehienbat; hala ere, lixibiatuen garbiketan ere erabiltzen dira [28]. Tratamendu kimikoen bitartez, kutsatzaileak deuseztatu, toxikotasun baxuagoko forma bihurtu, erauzi edo geldiarazi nahi izaten dira. Teknika eza- 
gunenen artean daude oxidazioa, erredukzioa, hidrolisia, solubilizazioa, deklorinazioa eta $\mathrm{pH}$ manipulazioa; hala ere, ikerkuntza oxidazioan/erredukzioan eta kutsatzaileen erauzketan ardaztu izan da batik bat [26, 32]. Tratamendu mota horiek oso espezifikoak izan daitezke PCB edo alkano halogenatuen antzeko kutsatzaileentzat [34]. Gainera, hainbat matrizetan aplika daitezke, baldin eta nahastura eraginkor bat bermatzen bada. Aldiz, lurreratutako kimikoek lurzorua kutsa dezakete (baldin eta guztiz erreakzionatzen ez badute); eta, kasu askotan, teknika horiek ez dira gai lurzoruko konposatu organikoen eta kutsatzaileen artean bereizteko; ondorioz, lurzoruko konposatuak degradatu edo kutsatzaileak tratatu gabe utz ditzakete.

Teknologia fisiko-kimiko horiek kutsatzaile askoren kontzentrazio-mailak jaisteko teknika apropos eta eraginkorrak direla frogatu dute $[35,36]$ azken hamarkadetan. Dena den, badituzte zenbait eragozpen ere; besteak beste, beren konplexutasuna, inplementazio-kostu altua, aplikagarritasun eskasa eskala txikian, edota gizartearen onespen eza [11, 37]. Gainera, ez dute lurzoruaren funtzionalitatea berreskuratzen, eta lurzoruaren funtzio ekologikoak galdu egiten dira. Aitzitik, tratamendu biologikoen gaineko arreta zeharo emendatu da azken urteotan, kutsatutako lurzoruetan dauden konposatuen degradazio, iraultze eta transformaziorako tresna ez-erasokor gisa $[11,38]$.

\subsection{Erremediazio biologikoa}

Ohiko teknikekin alderatuz, tratamendu biologikoak kutsatzaileen degradazio osoa (edo substantzia ez-toxiko bihurtzea) ahalbidetzen duten prozesu naturalak dira. Aplikazio erraz, merke eta malguak dira, ingurumen-baldintza askotarikoetan aplika daitezkeenak. Erremediazio mota hau hainbat organismorekin (edo organismo multzorekin) gauzatu daiteke; hots, mikroorganismo, landare edo/eta animaliekin. Bereziki aipagarriak dira bakterio, landare eta lurzoru ornogabeekin gauzatzen diren erremediazioak [26]; horien artean, laborantza, konpostatzea, biopilak, bioerreaktoreak, biolixibiazioa, fitoegonkortzea, fitoerauzketa, fitodegradazioa edo bermierremediazioa dira azpimarragarrienak [3].

\subsubsection{Bioerremediazioa landareak erabiliz: fitoerremediazioa}

Fitoerremediazioa lurzoru kutsatuak tratatzeko landareak erabiltzen dituen bioerremediazio-metodologia da. Bioerremediazio-teknika gisa gero eta onartuago dagoen teknika hori [39] bereziki egokia da kutsatzaileak landa-eremu zabalak hartzen dituenean edo sustrai-sakoneran daudenean [40]. Fitoerremediazioan emendio bat ikusten da kutsatzaileen degradazioetan, inguruko tratatu gabeko lurrekin alderatzen bada. Izan ere, teknologia horren bitartez, mikroorganismo-dentsitate eta jarduera altuagoak lortzen dira errizosferan [41-44], eta kutsatzaileen deuseztatzea, egonkortzea, finkatzea, degradatzea edo lurruntzea bultzatzen da. Gainera, landareen transpirazioak 
Erik Urionabarrenetxea, Nerea Garcia-Velasco, Mikel Anza, Unai Artetxe, Rafael Lacalle, Carlos Garbisu, Txema Becerril, Manu Soto

sustrai inguruetan disolbatuta dauden kutsatzaileak kanporatzea ahalbidetzen $\mathrm{du}[42,45]$. Beraz, kutsatzaileak zenbat eta disolbagarriagoak izan, orduan eta errazagoa izango da landareentzat horiek erauztea [46]. Hainbat mekanismoren bitartez lor daiteke fitoerremediazioa; horrela, fitoegonkortzea, fitolurrunketa/fitodegradazioa eta fitoerauzketa ditugu [3] (1. irudia).

Fitoegonkortzean landareak erabiltzen dira lurzoruko kutsatzaileak geldiarazteko (metal astunak, kasu), horien erosio edo lixibiazio bidezko bioeskuragarritasuna jaitsiz. Teknika hori fitoerauzketa gauzatu nahi ez denean [47] edo kutsadura-mailak erauzketa bidez jaisteko altuegiak direnean erabiltzen da gehienbat [48], denbora luzeegia har dezakeelako edo kutsadura-maila altuek landareen hazkuntza kaltetu dezaketelako [49]. Fitoegonkortzea kutsatzaileen prezipitazio, konplexaketa, sortzio edo metal balentziaren erredukzio (metalen kasuan) bitartez lortzen da batik bat [50]. Orokorrean, teknika oso baliagarria da kutsatzaileak azkar geldiarazi behar direnean; hala ere, gehienetan medeapenak erabili behar izaten dituzte. Erabili beharreko medeapenen menpekotasun horrek, erauzten ez den kutsaduraren beharrezko monitorizazioarekin batera, teknika zaurgarri bilakatzen dute fitoegonkortzea.

Fitolurrunketa bitartez, lurzoruko kutsatzaileak lurretik atera nahi dira. Horretarako, kutsatzaileak forma hegakor bilakatzen dira, eta, jarraian, atmosferara transpiratu [51]. Merkurioarekin (batez ere) eta selenioarekin kutsatutako lurzoruak erremediatzeko erabiltzen da batik bat teknika hori; konposatuak forma toxiko izatetik forma oinarrizko edo toxikotasun gutxiagoko izatera igarotzen dira. Edonola ere, teknika horren arazo nagusia sortutako produktuek eragin ditzaketen konplikazioak dira; hots, airean lurrundutako metal oinarrizkoak laku eta erreketara prezipitazio bitartez berrisurtzean sortuko liratekeenak. Izan ere, teknologia hori oso aproposa da transformazio horretan desagertzen edo deuseztatzen diren kutsatzaile organiko edo ez-iraunkorrekin erabiltzen baldin bada. Kutsatzaileak iraunkorrak badira, aldiz, teknologia horren bidez kutsatzaileak barreiatzea eta translokatzea besterik ez da lortzen; hau da, arazoa lekuz aldatzea.

Fitoerauzketa da, ordea, fitoerremediazio-formarik arruntena. Horren bitartez, lurrean dauden kutsatzaileak landareen hosto eta sustraietan metatzen dira [52]. Modalitate horretan erabiltzen diren landareak hazkuntza azkarrekoak, biomasa altukoak, sistema erradikular hedakorrekoak eta kutsatzaileak metatzeko zein jasateko gai izan ohi dira. Fitoerauzketaren arrakasta kutsatzaile motaren, bioeskuragarritasunaren eta landareen egokitasunaren menpe dago. Espezie hipermetatzaileek landare arruntek baino 10-500 aldiz metal gehiago metatu dezakete [40, 47, 52, 53]; fitoerremediaziorako espezie ezin hobeak dira. Hiperjasaileak izan ohi diren espezie horiek (espezie arruntek baino kutsatzaile-kontzentrazio altuagoak jasaten dituzte), konpartimentu bakuolarretan edota zelula-paretetan metatzen dituzte kutsatzaileak; azken horiek urrun mantentzen dituzte arnasketa, banaketa zelularra edo antzeko ezinbesteko beste funtzioak gauzatzen diren konpartimentu zelularretatik [40, 54]. Hipermeta- 
tzaileekin gauzatzen den fitoerauzketaren muga handienetako bat da erauzitako metalak elikadura-katean sartzea. Hala ere, hipermetatzailetzat hartuta dauden zenbait brasikazea (Brassicaceae familiako) espeziek tiozianato deritzen anioi kantitate handiak dituzte beren baitan $[40,52,55]$, eta horrek desatsegin bihurtzen ditu animalientzat. Hipermetatzaileen beste eragozpen bat da horiek daukaten hazkuntza-abiadura baxua eta biomasa txikia [56]. Horri aurre egiteko, alpapa (Medicago sativa), artoa (Zea mays), brasikazeak (Brassica napus, $B$. juncea eta $B$. rapa) edo antzeko hazkuntza eta biomasa handiko espezieak erabiltzen dira [57]. Fabaceae familiako Medicago generoa da fitoerremediazioan gehien erabiltzen den generoetako bat [58]. 87 espeziek osatzen duten arren, gutxi batzuk testatu dira fitoerremediazioan erabiltzeko. Alpapa espeziea dago espezie ezagunenen artean, zeina animalien bazkarako labore garrantzitsua baita [59]. Bazkalekuek edo larreek baino hobeto jasan ditzakete lehorteak; aldiz, ez daude lurzoru azido edo eskas drainatuetara egokituak [39, 60]. Kutsatzaileekiko erresistentea den eta biometatzaile egokia den espezie hori [61, 62] biomaterial egokia dela frogatu da metal astunen eliminazio eta erremediaziorako [49]. Bestalde, oso ezagunak dira petrolio hidrokarburoekin kutsatutako lurren erremediazioan alpapak lor ditzakeen errendimenduak; hala nola, $\mathrm{PAH}$ deuseztatzea [44, 58, 63-68], eta benzo(a)pirenoa \% 64an (medeagarririk gabeko lurzoruan) eta \% 54an (medeagarridun lurzoruan) jaistea [69].

Kasu gehienetan, landareek lurzoruan arinki eskuragarri dauden metalak absorbatzen dituzte. Beste batzuetan, aldiz, metalak prezipitatu disolbaezin bezala egoten dira, landareentzat eskuraezin. Kasu horietan, substantzia kelanteen adizioak (bereziki EDTA eta/edo EDDS) metalen prezipitazioa saihesten du, eta metal kelatu konplexuen bidezko absortzioa hobetzen; ondorioz, bioeskuragarritasuna emendatzen da [48].

A

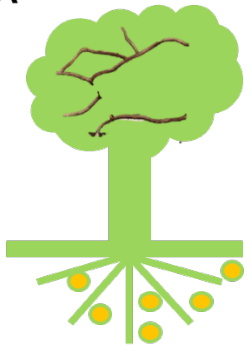

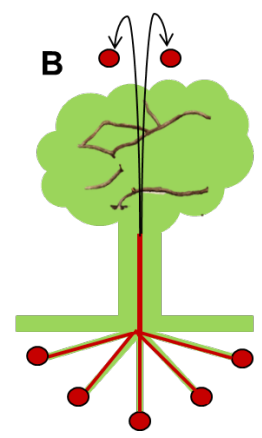

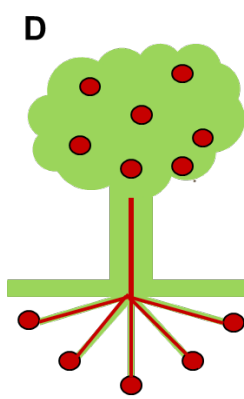

1. irudia. Fitoerremediazio-mekanismoak; kutsatzaileak egonkortzea dakarren fitoegonkortzea (egonkortutako kutsatzaileak horiz irudikatuta) (A), kutsatzaileak lurruntzea dakarren fitolurrunketa (kutsatzaileen lurretik airerako fluxua irudikatuta) (B), kutsatzaileen deusezte totala edo partziala (ilargi-itxurako metaketak) eragiten duen fitodegradazioa $(\mathrm{C})$, eta fitoerauzketa (kutsatzaileen metatzea biomasan irudikatuta) (D). Borobilak: kutsatzaileak. 
Erik Urionabarrenetxea, Nerea Garcia-Velasco, Mikel Anza, Unai Artetxe, Rafael Lacalle, Carlos Garbisu, Txema Becerril, Manu Soto

Erremediazio-teknika horiek, kutsadura-arriskuaren kontrol eta murrizketarako erabiltzen diren heinean, merkatu-balioa duten biomasa produzitzeko erabiltzen badira, fitomaneiatze-estrategiak aplikatzen direla jotzen da [70, 71]. Fitomaneiatzearen fokatze horrek baliabide erabilgarri gisa ulertzen ditu kutsatutako lurzoruak, era jasangarrian ustia daitezkeen lurzoru gisa. Munduko lurzoru kutsatuak bioenergia, egur, pulpa, bio-ikatz edo zuhainaren produkziorako erabil daitezke [72]; kasu batzuetan, produktuari balioa gehitzen diote, zinkak biosendotutako materialetan kasu. Fokatze horrek zoru emankorren gaineko presioa leuntzea eta kutsatutako lurrak hobetzea dakar (epe luzera); era berean, sortutako irabazi ekonomikoek proiektuaren kostua (ko)finantzatu dezakete [70].

\subsubsection{Bioerremediazioa, mikroorganismoak erabiliz}

Bakterioekin gauzatzen diren bioerremediazio-estrategiak - indargabetze naturala, bioestimulazioa edo bioareagotzea kasu [73] - in situ edo ex situ burutu daitezke. Ex situ tratamenduak, gehien erabiltzen direnak diren arren [52], lurzorua induskatzea eta teknologiak aplikatuko direneko lan tokira garraiatzea suposatzen dute; in situ lanak, aplikagarriagoak eta erosoagoak dira [11].

Estatu Batuetako EPAren arabera (1999) (Environmental Protection Agency), indargabetze naturala da prozesu naturalen bidez kutsadura-isuriei eustea eta horiek jaistea. Prozesu natural horietan, barne hartzen dira degradazio biologikoa, lurrunketa, dispertsioa, diluzioa, desintegrazio erradioaktiboa eta MO zein kutsatzaile mineralen sortzioa [74]. Beraz, indargabetze naturala lekuko lurrazpiko geologiak, hidrologiak eta mikrobiologiak baldintzaturiko prozesua izango da. Gehienbat bentzenoak, toluenoak, etil bentzenoak, xilenoak eta hidrokarburoak degradatzeko erabiltzen den arren, konposatu inorganikoak eta pestizidak degradatzeko potentziala duen teknika da [74] (2. irudia). Aitzitik, teknologia hori oso motela izatera hel daiteke; batez ere, biodegradazioa ingurumen-faktore batez edo gehiagoz (hotza, lehorteak, etab.) baldintzatuta dagoenean.

Jarduera mikrobiano hori mugatzen duten baldintzen manipulazioa egiten denean, konposatu kutsatzaileen metabolizazioa bultzatu nahian, bioestimulazioaz ari gara $[11,52]$. Prozesu horrek mikroorganismoek karbono-iturri gisa erabiliko dituzten nutrienteak gehitzea barne hartzen du; gorotzak, medeagarri organikoak [52], egur txirbilak edo NPK (nitrogeno, fosforo, potasio) nutrienteak gehituz [11] lor daiteke hori. Gehitutako nutrienteek erremediazio-prozesuan funtsezkoak diren mikroorganismoen hazkuntza eta jarduerak emendatzen dituzte; ondorioz, eraginkortasuna handitzen dute. Bioestimulazioa, batik bat PAHak bezalako kutsatzaile organikoen degradaziorako erabiltzen den arren [76, 77], metal astunen erremediaziorako ere erabil daiteke [52]; adibidez, metalen bioeskuragarritasunean eragingo duen lurzoruaren $\mathrm{pH}-\mathrm{a}$ eraldatuz. 

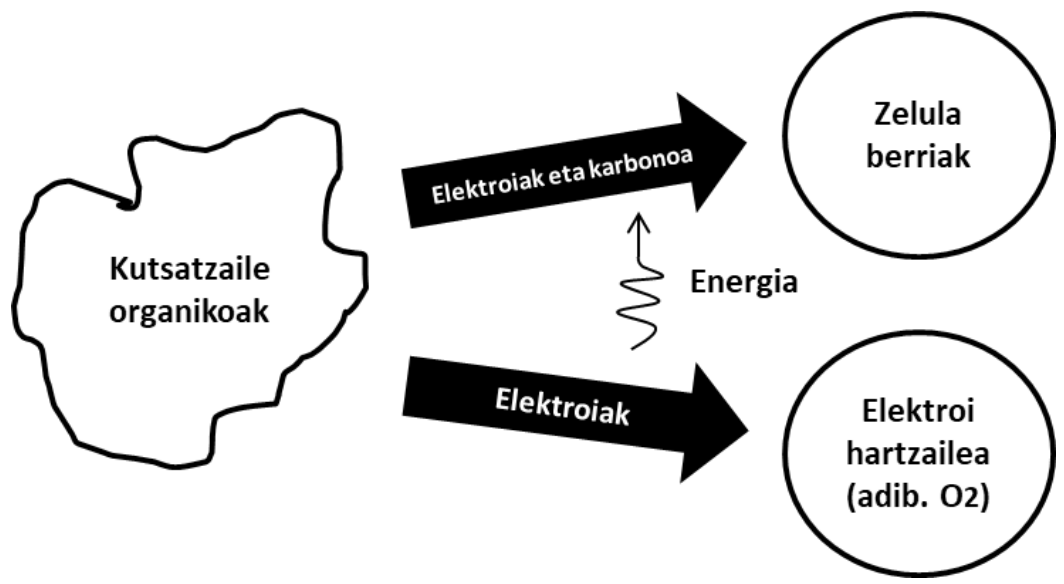

2. irudia. Kutsatzaile organikoen eta mikroorganismoen arteko elkarrekintza. Yeung et al., 2010etik [73] eraldatutako irudia. Kutsatzaile organikoek bi eratan hornitzen dituzte mikroorganismoak: (1) zelula berriak eratzeko karbono-iturri gisa eta (2) mikroorganismoek energia lortzeko elektroiak emanez; izan ere, mikroorganismoek energia lortu ahal izango dute erreakzio kimikoak katalizatuz; lotura kimikoak apurtuz, adibidez.

Orain arte aipatutako teknikak lurzoruen erremediazioan oso erabiliak diren arren, bioareagotzea da hedatuena bioerremediazio mikrobianoari dagozkion tresnen artean. Bioareagotzea lurzoru kutsatzaileen degradazioa emendatzeko ahalmen katalitikoak dituzten bakterio-andui edo bakterio-kontsortzioen inokulazioan datza [78-81]. Autore askok frogatu izan dute bioareagotzearen baliagarritasuna konposatu organiko ezberdinekin kutsatutako lurren bioerremediazioan [77]; kutsatzaileen degradazioa bultzatuz, kutsatzaileak mineralizatuz edo kaltegarriak ez diren konposatu bilakatuz [11]. Gainera, zabalki frogatu izan da mikroorganismoek gauzatu ditzaketen biometaketa-, bioeraldaketa-, biomineralizazio-, kimiosortzio-, biosortzio- edo biometilazio-prozesuek metal astunen bioeskuragarritasuna zein toxikotasuna mugatu dezaketela [82]. Adibidez, Garbisuk eta bestek [83] ikusi zuten Bacillus subtilis baziloa gai zela selenita toxikotasun baxuagoko Se oinarrizko bihurtzeko. Teknika honetan erabiliko diren mikoorganismoek, kutsatzaileak erauzteko edo deuseztatzeko gai izateaz gain, gai izan behar dute ingurumenera egokitzeko eta bertan bizi diren mikrobiota autoktonoekin karbono-iturri eskasengatik lehiatzeko [84]. Horren ondorioz, eta askotan organismo aloktonoek lurzoru- komunitatean parte izatea lortzen ez dutela jakinda [11], gomendagarria izaten da mikroorganismo autoktonoak erabiltzea bioerremediazio-tekniketan [85]. 
Erik Urionabarrenetxea, Nerea Garcia-Velasco, Mikel Anza, Unai Artetxe, Rafael Lacalle, Carlos Garbisu, Txema Becerril, Manu Soto

Burkholderia xenovorans LB400 anduia (lehenago Pseudomonas sp. LB400, Burkholderia sp. LB400, Burkholderia fungorum LB400 deitua) graminis kladoaren parte da; sarritan aurkitu daiteke larre-landareetako errizosferan [86]. Nitrogeno-finkatzailea den espezie hori [87] PCBekin New Yorken kutsatutako lurzoru batetik isolatu zen [88]; gaur egun, ezagutzen den PCB degradatzailerik garrantzitsuenetako bat da (20 PCB kongeneretik gora oxidatzeko gai da) [89-91]. Gainera, LB400 anduiak moldakortasun kataboliko handia erakutsi izan du konposatu aromatikoen degradaziorako [88, 92], eta uzten hazkuntza ere bultzatu dezake [87]. Izan ere, landareen hazkuntza bultzatzen duen nitrogenoa finkatzeaz gain, 1-amino-ziklopropano1-karboxilato (ACC) deaminasa entzima bakterianoak ACCa (etilenoaren aintzindaria) hidrolizatu eta etileno-mailak jaisten ditu; ondorioz, sustraiak haztea bultzatzen du [87-93].

\subsubsection{Bioerremediazioa, zizareak erabiliz: bermierremediazioa}

Bermierremediazioan, zizareak erabiltzen dira beren jardueraren bitartez MO bermi-konpost bilakatzeko [94-96]. Beste erremediazio-teknika batzuekin konbinazioan garatu daitekeen in situ teknika merkea da [97, 98]. Bioerremediazio-prozesuek irauten duten bitartean, beharrezkoa izaten da lurzoruen hezetasun-, oxigeno- eta nutriente-mailak homogeneoki mantentzea, batez ere, erremediatu beharreko lurrak sakonak, trinkoak edo buztinean aberatsak direnean [98]. Zizareek laguntzen dute baldintza horiek lurzoruan mantentzen; horretarako, ur-, partikula-, nutriente- eta aireaziomugimenduak erraztuko dituzten tunelak eraiki behar dira [98-100]. Horrela, lurzoruen porotasuna $[99,101]$, oxigenazioa, hezetasunaren atxikitzea/gordetzea/metatzea, lurzoruaren emankortasuna, eta nutrienteen eskuragarritasuna emendatzen dira [102] (3. irudia). Prozesu horiekin batera, lurzoruko partikulen birrintze mekaniko bat gertatzen da gainera, partikula organikoak eta lurzoruko materialak txikituz [99]. Horrela, partikula horien gainazal-azalera handitu egiten da [102], eta material-mikrorganismo interakzioa bultzatzen da [100].

Zizareen presentziak, lurzoruetako faktore abiotikoak eragiteaz gain, baldintza biotikoak ere eragiten ditu; adibidez, mikroorganismoen jarduera emendatzen du. Bestetik, zizareek barrunbeko paretetan utzitako mukiek eta gorotzek, bertako karbono organikoarekin batera, mikroorganismoak haztea eta barreiatzea sustatzen dute $[98,103]$. Era berean, mukiek, gernuak eta glukosak mikrobio-biomasa (eta jarduera katabolikoa) emendatzen dute. Lurzoru-populazio mikrobianoen dibertsitatea, kantitatea eta jarduerak zizareen liseri-traktuko mikroorganismoen igarotze, promozio eta berpiztearekin erlazionatu izan dira [98, 104]; hala ere, promozio hori liseriketa-denborak baldintzatu du zeharo [104]. Lurzoruan zeharreko mikroorganismoen barreiatzea, ordea, zizareen azalerara atxikiz [102] eta barrunbeen bitarteko ur-fluxuen bidez [99] gertatzen da. 
Bermierremediazioa zabalki ikertu izan da kutsatzaileak deuseztatzean, batez ere, kutsatzaile organikoen aurrean erakutsi izan duen eraginkortasun altuagatik. Horrela, hainbat lanetan zizareak erabiltzen dituzte intsektizida [106], herbizida [107], PAH [105, 108-113], PCB [114-115] zein metal astunen [113, 116-118] biorremediazioan.

Espeziea erremediatu beharreko lurzoru motaren, kutsatzaile motaren, zein elikagai-eskuragarritasunaren araberakoa izan behar da [102]. Hala ere, espezieen artean Eisenia fetida espeziea da, zalantzarik gabe, erabiliena [98]. Izan ere, maneiatzeko errazak diren zizare horiek gainartzaile bilakatzen dira beste zizare-espezie batzuekin elkartutako sistemetan [100].

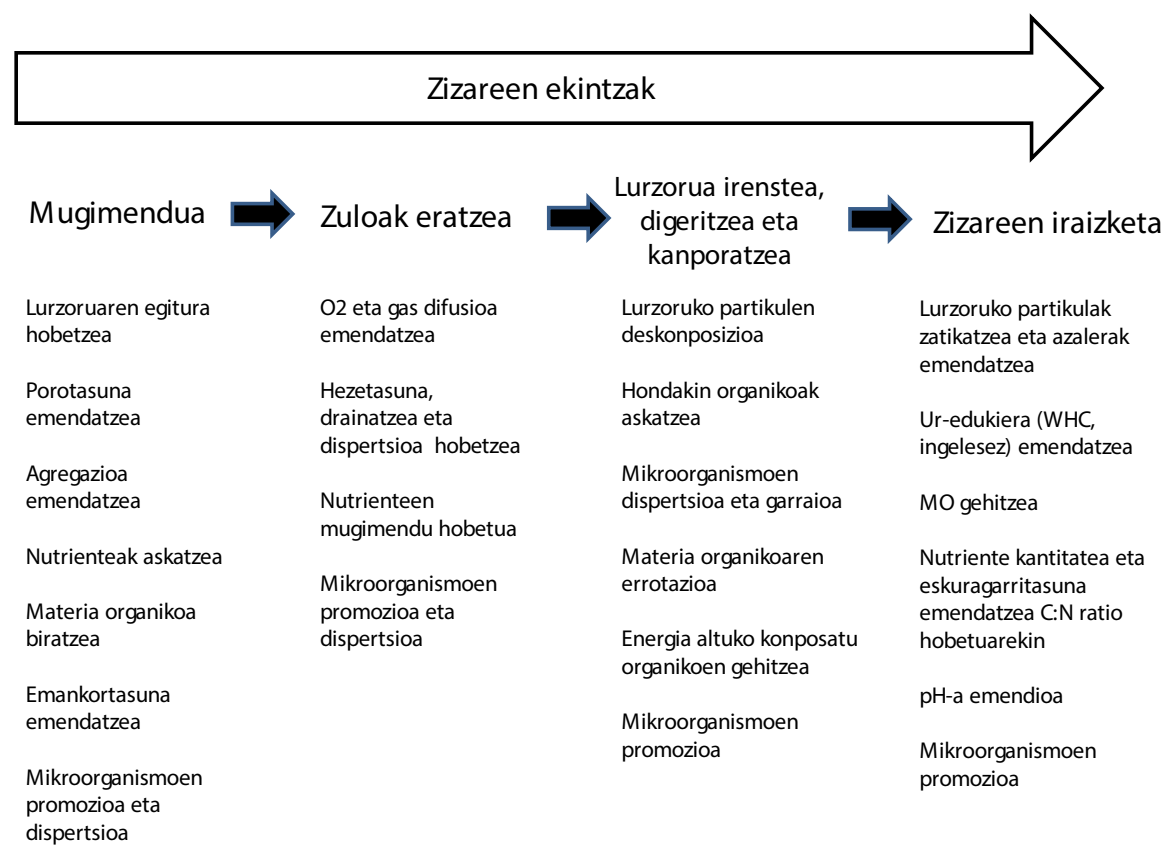

3. irudia. Zizareek lurzoruan eragindako efektu biologiko, kimiko eta fisikoak. Hickman eta Reid autoreetan [98] oinarrituta.

\subsubsection{Bioerremediazio-tekniken konbinazioaren bilaketa}

Bioerremediazio-teknologien erabilera eta ikerkuntza zeharo hazten ari da. Hala ere, teknika horiek bakarkako konposatuen bioerremediazioa hobetzera bideratu dira batik bat [119], eta ikerketa gutxi egin da kutsatzaile-nahasketa duten lurzoruen gainean. Horren arrazoia kutsadura anitzeko lurzoruen konplexutasunean eta bioerremediazio-tratamenduen kutsatzaileenganako aldagarritasunean datza [120]. Bioerremediazio-prozesu oro- 
Erik Urionabarrenetxea, Nerea Garcia-Velasco, Mikel Anza, Unai Artetxe, Rafael Lacalle, Carlos Garbisu, Txema Becerril, Manu Soto

tan, elkarrekintza konplexuan dabiltzan faktore fisiko-kimiko eta biologikoek eta lurrean dauden kutsatzaileek elkarri eragin diezaiokete, eta horien eskuragarritasuna eta mugikortasuna aldatu. Era berean, bioerremediazio mota ezberdinetan diharduten organismoek aldaketak jasan ditzakete hazkuntzan eta metabolismoan, eta, ondorioz, prozesuaren errendimendua erasan. Adibidez, konposatu inorganiko askok konposatu organikoak degradatzen dituzten mikroorganismoen jarduera inhibi dezakete [121]. Bestalde, sor daitezkeen interakzioen artean, badira errendimendua bultzatu dezaketen interakzioak ere. Mikroorganismoen eta landareen arteko erabilera konbinatua (4. irudia) kutsatutako lurzoruak erremediatzeko teknika arinagoa eta efizienteagoa dela ikusi da [48, 122-124]. Onura horiek mikorriza-elkarrekintzei esker gertatzen dira batik bat, kutsatutako lurretan landareen hazkuntza eta bizirautea ahalbidetzen duten horiei esker. Hala ere, badira errizosferan dauden eta erremediazio-prozesuetan oso erabiliak diren errizobakterioak ere (4. irudia). Horiek hainbat mekanismo erabil ditzakete landareen hazkuntza bultzatzeko: fitohormonak produzitu eta elikagaiak gehi ditzakete [125]; sideroforoak edo beste agente kelante batzuk ekoitz ditzakete [126]; entzima espezifikoak ekoitzi edo N-a finkatu dezakete [127]; edo sustrai-hazkuntza bultza dezakete etileno-produkzioa jaitsiz $[52,128]$.

Bestalde, zizareen eta bakterioen arteko erlazioa interdependentea dela ikusi izan da; ondorioz, beren arteko interakzioek populazio-tamainak edo isuritako entzimak kontrola ditzakete $[112,129]$ (4. irudia). Horren harira, Hong-ek eta bestek [130] E. fetida zizareen liseri-traktuetako komunitate bakterianoak identifikatu eta sailkatu zituzten; aerobioen artean, Aeromonas (\% 40), Bacillus (\% 37), Photobacterium (\% 10), Pseudomonas (\% 7), eta Shewanella (\% 6) generoko bakterioak, eta, anaerobioen artean, Aeromonas (\% 52), Bacillus (\% 27), Shewanella (\% 12), Paenibacillus (\% 5), Clostridium (\% 2), eta Cellulosimicrobium (\% 2) generoko bakterioak aurkitu zituzten. Genero horietako batzuk -Bacillus [131], Clostridium [131], Pseudomonas [132], Streptomyces [133] eta Shewanella [134] kasu - gai dira hainbat konposatu organiko degradatzeko (18 konposatutatik gora: ziklohexanoak, bentzenoak, etilbentzenoak, kloroformoak, metanolak eta azetonak; [131]), eta metalen erredukzioan laguntzeko [132, 134].

Ohiko esperimentuetan, bioerremediazio-errendimenduan eragina izan dezaketen faktoreak banan-banan ikertu izan dira, bakoitzaren efektua zenbatetsi nahian. Horrek, denbora dezente galarazteaz aparte, informazio asko galtzea ere eragin du; hain zuzen ere, aldagaien arteko interakzio ebentualei dagokiona [135]. Horretarako, ezinbestekoa da errealitatera gehien hurbiltzen diren eta berezko mugak saihesten dituzten teknikak edo konbinazioak erabiltzea. Izan ere, era horretan bakarrik agerraraziko dira teknika bakoitzaren mugak eta tekniken arteko sinergia, adizioa edo kontrajartzeak, eta errazago ulertuko dira tekniken arteko erlazioak. 


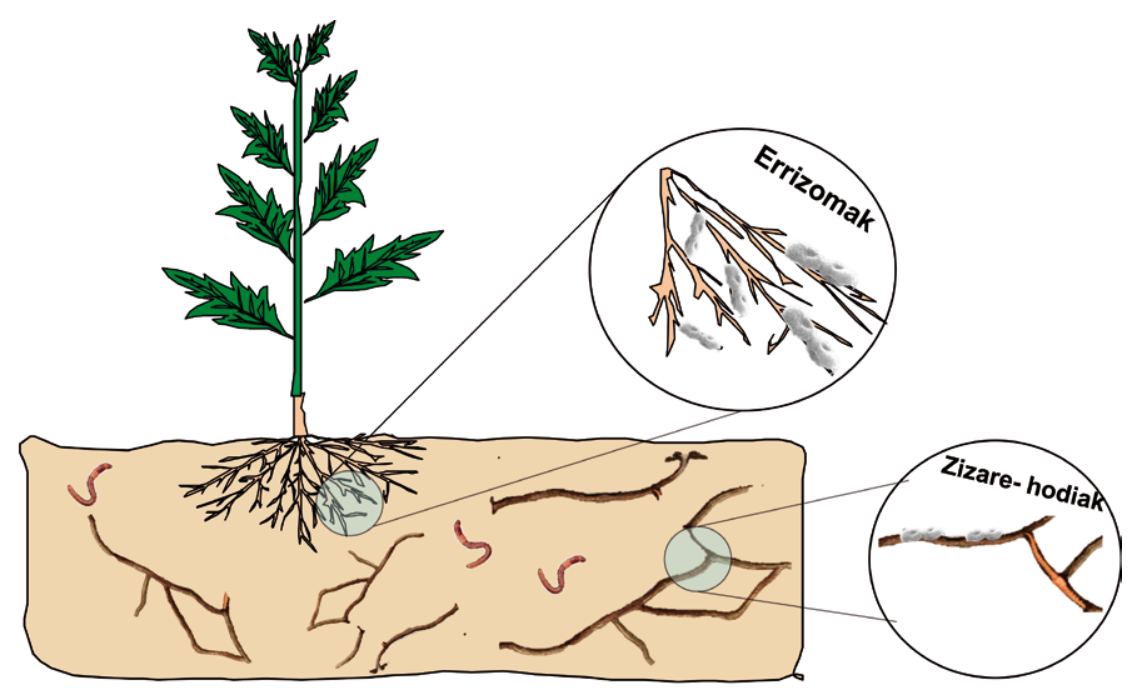

4. irudia. Lurzoru kutsatuak erremediatzeko bermierremediazio-, mikroerremediazio- eta fitoerremediazio-tekniken elkarrekintza. Zizareen eta landare-sustraien arteko errizomak, zizare-hodiak eta zizare-hodietako bakterio-komunitateak irudikatzen dira.

\section{ESKER ONAK}

Egileen esker onak MINECOko CTM2017-87766-R proiektuari, Biorem proiektuari (IHOBE, Ekoberrikuntza 2017 deialdia) eta Gernikako Udalari, elkarrekin xedatutako hitzarmenak (2018/12/11) ahalbidetu baitu lan hau.

\section{BIBLIOGRAFIA}

[1] Hooda, P. 2010. Trace Elements in Soils. 10.1002/9781444319477.

[2] Cachada A., Rocha-Santos T., Duarte, A. C. 2018. Chapter 1 - Soil and Pollution: An Introduction to the Main Issues. Editor(s): Armando C. Duarte, Anabela Cachada, Teresa Rocha-Santos. Soil Pollution. Academic Press, $1-28$,

[3] Gómez-Sagasti, M. T., Epelde, L.; Barrutia, O. 2019. Fitorremediazioa lurzoru kutsatuen kudeaketa iraunkorrerako estrategia gisa. Ekaia, 35, 2019, 197-212.

[4] Gómez-Sagasti, M.T., Alkorta, I., Becerril, J.M., Epelde, L., Anza, M., Garbisu, C., 2012. Microbial monitoring of the recovery of soil quality during heavy metal phytoremediation. Water Air Soil Pollut. 223, 3249-3262. 
Erik Urionabarrenetxea, Nerea Garcia-Velasco, Mikel Anza, Unai Artetxe, Rafael Lacalle, Carlos Garbisu, Txema Becerril, Manu Soto

[5] Lukkari T., Taavitsainen M., Väisänen A., Haimi J.. 2004. Effects of heavy metals on earthworms along contamination gradients in organic rich soils. Ecotox.and Environ. Saf.

[6] Hopkin, S.P., 1989. Ecophysiology of Metals in Terrestrial Invertebrates. Elsevier, London.

[7] Pelosi, C., Barot, S., Capowiez, Y. Hedde M., Vandenbulcke F. 2014. Pesticides and earthworms. A review. Agron. Sustain. Dev. 34, 199-228.

[8] Lowe CN, Butt KR. 2007. Earthworm culture, maintenance and speciesselection in chronic ecotoxicological studies: a critical review. Eur. J. Soil. Biol. 43:S281-S288.

[9] Brusseau, M.L., 1997. Transport and fate of toxicants in soils. In: Tarradellas, J., Bitton, G., Rossel, D. (Eds.), Soil Ecotoxicology.Lewis, New York, pp. 33-53.

[10] Betancur-Corredor B., Pino N., Penuela G.A., Cardona-Gallo S. 2013. Biorremediacion de suelo contaminado con pesticidas: caso DDT. Revista Gestión y Ambiente. 16: 119-135.

[11] Aparicio, J.D. 2018. Biorremediación de suelos contaminados con Cr(vi) y lindano por actinobacterias Universidad nacional de Tucumán. Facultad de bioquímica, química y farmacia.

[12] Cerniglia, C.E.1992. Biodegradation of polycyclic aromatic hydrocarbons. Biodegradation 3:351-368.

[13] Mohan V., Kisa T., Ohkuma T., Kanaly R.A., Shimizu Y. 2006. Bioremediation Technologies For Treatment Of PAH-contaminated Soil And Strategies to Enhance Process Efficiency. Rev.Env. Sci. \& Bio/Techn. 5. 347-374.

[14] Evanko, C.R. and Dzombak, D.A. 1997. Remediation of Metals-Contaminated Soils and Groundwater. Tech. Eval. Rep., 61 p.

[15] Giller K.E., Witter E., McGrath S.P. 1998. Toxicity of heavy metals to microorganisms and microbial processes in agricultural soils: a review. Soil Biol. Biochem.y, 30: 1389-1414.

[16] Wild, A., Ed. 1988. Russell's Soil Conditions and Plant Growth, 11th Edition, Longman, London.

[17] Dzombak, D.A. and Morel F.M.M. (1987), «Adsorption of Inorganic Pollutants in Aquatic Systems,» J. Hydraulic Eng., 113:430-475.

[18] Jacobson, A.R., McBride, M.B., Baveye, P., Steenhuis, T.S., 2005. Environmental factors determining the trace-level sorption of silver and thallium to soils. Sci Total Environ 345, 191-205.

[19] Ellis, W.D. and Fogg, T. (1985) Interim Report: Treatment of Soils Contaminated by Heavy Metals, Hazardous Waste Engineering Research Laboratory, Office of Research and Development, U.S. EPA, Cincinnati, Ohio.

[20] Sposito, G. (1989), The Chemistry of Soils, Oxford University Press, New York.

[21] Nieder, R. and Benbi, D.K., 2008. Soil organic matter characterization. Carbon and nitrogen in the terrestrial environment, in: (Ed.), pp. Carbon and nitrogen in the terrestrial environment, Springer Netherlands, 81-111. 
[22] Garcia-Velasco, N. 2017. Toxicity assessment of silver nanoparticles in soils through standard tests, an integrated battery of biomarkers at different levels of biological complexity and in vitro approaches with coelomocytes in Eisenia fetida. Euskal Herriko Unibertsitatea. Basque Country.

[23] Kibblewhite, M.G., Ritz, L., Swift, M.J. 2008. Soil health in agricultural systems. Phil Trans R Soc B 363, 685-701.

[24] Ali, M.A. and Dzombak, D.A. 1996. «Interactions of Copper, Organic Acids, and Sulfate in Goethite Suspensions,» Geochim. Cosmochim. Acta, 60: 5045-5053.

[25] Cornellis, G., Thomas, C.D.M., McLaughlin, M.J., Kirby, J.K., Beak, D.G., Chittleborough, D., 2012. Retention and dissolution of engineered silver nanoparticles in natural soil. Soil Sei Soc Am J 76, 891-902

[26] Scullion J. Remediating polluted soils. Naturwissenschaften. 2006 Feb;93(2):51-65.

[27] Sparks D.L., Corn M. 1993. Handbook of Hazardous Materials (Academic Press, San Diego,).

[28] Armishaw R., Bardos R.P., Dunn R.M.,. Hill J.M, Pearl M., Rampling T., Wood P.A.. 1992 Review of Innovative Contaminated Soil Clean-up Processes Warren Springs, Stevenage,

[29] Castelo-Grande T., Augusto P.A., Monteiro P., Estevez A.M., Barbosa D. 2010: Remediation of soils contaminated with pesticides: a review. Intern. Journ. Environ.1 Anal.Chemis., 90:3-6, 438-467.

[30] Taube, F., Pommer, L. Larsson, T., Shchukarev, A. Nordin, A. 2008. Soil Remediation - Mercury Speciation in Soil and Vapor Phase During Thermal Treatment. Wat. Air Soil Pollu. 193. 155-163.

[31] Shen Z., Pan S., Hou D., O'Connor D., Jin F., Mo L., Xu D., Zhang Z., Alessi D.S. 2019.Temporal effect of $\mathrm{MgO}$ reactivity on the stabilization of lead contaminated soil. Environ. Intern.. Vol. 131, 104990.

[32] Mulligan, C.N., Yong, R.N., Gibbs, B.F..2001. Remediation technologies for metal contaminated soils and ground water: an evaluation. Eng Geol 60:193-207.

[33] Page, M., and Page, C. 2002. Electroremediation of Contaminated Soils. Journal of Environmental Engineering-asce - J environ eng-asce. 128. 10.1061/(ASCE)0733-9372(2002)128:3(208).

[34] Wood, P 2001 Remediation methods for contaminated land. In: Hester RE, Harrison RM (eds) Assessment and reclamation of contaminated land. Issues in environmental science and technology. Roy. Soci. Chem., pp. 115-139.

[35] Kastanek F., Topka P., Soukup K., Maleterova Y., Demnerova K., Kastanek P., Solcova O. 2016.Remediation of contaminated soils by thermal desorption; effect of benzoyl peroxide addition. Jour.Clean. Prod. 125, 309-313.

[36] Cai, Z., Zhao, X., Duan, J., Zhao D., Dang Z., Lin Z. 2020. Remediation of soil and groundwater contaminated with organic chemicals using stabilized nanoparticles: Lessons from the past two decades. Front. Environ. Sci. Eng. $14,84()$. 
Erik Urionabarrenetxea, Nerea Garcia-Velasco, Mikel Anza, Unai Artetxe, Rafael Lacalle, Carlos Garbisu, Txema Becerril, Manu Soto

[37] Niti C., Sunita S., Kamlesh K., Rakesh K. 2013. Bioremediation: An emerging technology for remediation of pesticides. Rese.Journ. Chem. Environ.. 4: 88-105.

[38] Salinas R., García M., Velásquez A. 2015. Ensayo. Biotecnología y etnomedicina para el desarrollo humano. Crea Ciencia 9: 39-45.

[39] Chekol, T. \& Vough, L.R. 2001. A Study of the Use of Alfalfa (Medicago sativa L.) for the Phytoremediation of Organic Contaminants in Soil. Remed. Journ. 11. 89 - 101. 10.1002/rem.1017

[40] Garbisu, C. and Alkorta, I. 2003. «Basic concepts on heavy metal soil bioremediation», Europ. Jour. Min. Process. E nviron. Protec 3(1), pp. 58-66.

[41] Cunningham, S.D., Anderson, T.A., Schwab, A.P., Hau, F.C., 1996. Phytoremediation of soils contaminated with organic pollutants. Adv. Agron. 56, 55-114.

[42] Liste, H., Alexander, M., 2000. Plant-promoted pyrene degradation in soil. Chemosphere 40, 7-15.

[43] Adam, G., Duncan, H., 2002. Influence of diesel fuel on seed germination. Environ. Pollut. 120, 363-370.

[44] Fan, S., Li, P., Gong, Z., Ren, W., He, N.. 2008.Promotion of pyrene degradation in rhizosphere of alfalfa (Medicago sativa L.), Chemosph., 71, 8, 1593-1598,

[45] Ferro, A.M., Sims, R.C., Bugbee, B., 1994. Hycrest crested wheatgrass accelerates the degradation of pentachlorophenol in soil. J. Environ. Qual. 23, 272-279.

[46] Nyer, E.K., Gatliff, E.G., 1996. Phytoremediation. Ground Water Monitoring Remediation 16, 58-62.

[47] Chaney, R.L., Malik, M., Li, Y.M., Brown, S.L., Brewer, E.P., Angle, J.S., and Baker, A.J.M. 1997. Phytoremediation of soil metals. Curr. Opin. Biotech., 8, 279-284.

[48] Marques P. G. C., Rangel A. O. S. S., and Castro P. M. L., «Remediation of heavy metal contaminated soils: phytoremediation as a potentially promising clean-up technology,» Crit. Rev. Environ. Sci. Techn.,. 39,. 8,. 622-654, 2009.

[49] Jadia, C.D., and M.H. Fulekar. «Phytotoxicity and remediation of heavy metals by Alfalfa (Medicago sativa) in soil-vermicompost media.» Advances in Natural and Applied Sciences,. 2,. 3, 2008,. 141+. Gale Academic OneFile.

[50] Adriano D. C., Wenzel W. W., Vangronsveld J., Bolan N. S. 2004 «Role of assisted natural remediation in environmental cleanup,» Geoderma, vol. 122, no. 2-4, pp. 121-142,

[51] United States Environmental Protection Agency (USEPA). 2000 «Introduction to phytoremediation,» EPA 600/R-99/107, U.S. Environmental Protection Agency, Office of Research and Development, Cincinnati, Ohio, USA.

[52] Chubuike, G.U. \& Obiora, Smart. 2014. Heavy Metal Polluted Soils: Effect on Plants and Bioremediation Methods. Applied and Environmental Soil Science. 2014. 1-12. 10.1155/2014/752708.

[53] Wenzel, W.W., Adriano, D.C., Salt, D., \& Smith, R. (1999). Phytoremediation: A plantmicrobe- based remediation system. In Adriano et al. (Eds.), Bioremediation of contaminated soils (Agronomy Monograph No. 37, pp. 457-508). Madison,WI: ASA, CSSA and SSSA. 
[54] Salt, D.E., Smith, R.D., Raskin, I., Phytoremediation. Annu. Rev. Plant Physiol. Plant Mol. Biol., 1998, 49, 643-668.

[55] Navari-Izzo, F. \& Quartacci, M.F., 2001. Phytoremediation of metals. Minerva Biotechnol., 13, 73-83.

[56] VanGinneken L., Meers E., Guissonet. R. 2007. «Phytoremediation for heavy metal-contaminated soils combined with bioenergy production,» Jour. Environ. Engin. Lands. Manage.,. 15,4,. 227-236.

[57] Ebbs S. D., Kochian L. V. 1997 «Toxicity of zinc and copper to Brassica species: implications for phytoremediation,» Journal of Environmental Quality, vol. 26, no. 3, pp. 776-781.

[58] Panchenko L, Muratova A, Turkovskaya O. 2017. Comparison of the phytoremediation potentials of Medicago falcata L. And Medicago sativa L. in aged oil-sludge-contaminated soil. Environ Sci Pollut Res Int. Jan;24(3):3117-3130. doi: 10.1007/s11356-016-8025

[59] Sengupta-Gopalan C, Bagga S, Potenza C, Ortega JL (2007) Alfalfa. In: Pua EC, DaveyMR (eds) Biotechnology in agriculture and forestry, Transgenic Crops VI, vol 61. Springer-Verlag, Berlin Heidelberg, pp. 321-335.

[60] Barnes, D.K., Shaeffer, C.C. (1995). Alfalfa. In Barnes, Miller, \& Nelson (Eds.), Forages vol. 1: An introduction to grassland agriculture (5th ed., pp. 205-216). Ames, IA: Iowa State University Press.

[61] Carrillo G. R., Cajuste L. J., J Environ Sci Health. Part A: Environ Sci. Eng Toxicol., 27, 1771 ( 1992).

[62] Wang, F., Li, Y., Zhang, Q., \& Qu, J. 2016. Phytoremediation of cadmium, lead and zinc by Medicago sativa L. (alfalfa) : A study of different period. Bulg Chem Commun., 47, SI, D, 167-172.

[63] Nichols TD, Wolf DC, Rogers HB, Beyrouty CA, Reynolds CM. 1997. Rhizosphere microbial populations in contaminated soils.Water Air Soil Pollut 95:165-178.

[64] Criquet S, Joner E, Leglize P, Leyval C. 2000. Anthracene andmycorhiza affect the activity of oxidoreductases in the roots and the rhizosphere of lucerne (Medicago saliva L.). Biotechnol Lett 22:1733-1737.

[65] Kirk JL, Klironomos JN, Lee H, Trevors JT. 2005. The effects of perennial ryegrass and alfalfa on microbial abundance and diversity in petroleum contaminated soil. Environ Poll 133:455-465.

[66] Schwab P, Banks MK, Kyle WA. 2006. Heritability of phytoremediation potential for the alfalfa cultivar Riley in petroleum contaminated soil. Water Air Soil Pollut 177:239-249.

[67] Phillips L, Greer CW, Germida JJ. 2006. Culture-based and cultureindependent assessment of the impact of mixed and single plant treatments on rhizosphere microbial communities in hydrocarbon contaminated flare-pit soil. Soil Biol Biochem 38:2823-2833.

[68] Phillips LA, GreerCW, Farrell RE, Germida JJ. 2009. Field-scale assessment of weathered hydrocarbon degradation by mixed and single plant treatment. Appl Soil Ecol 42:9-17. 
Erik Urionabarrenetxea, Nerea Garcia-Velasco, Mikel Anza, Unai Artetxe, Rafael Lacalle, Carlos Garbisu, Txema Becerril, Manu Soto

[69] Hamdi H., Benzarti S., Aoyama I., Jedidi N. 2012. Rehabilitation of degraded soils containing aged PAHs based on phytoremediation with alfalfa (Medicago sativa L.). International Biodeterioration \& Biodegradation. Vol 67, 40-47.

[70] Robinson, D.A., I. Lebron, and H. Vereecken. 2009. On the definition of the natural capital of soils: A framework for descripton, evaluation, and monitoring. Soil Sci. Soc. Am. J. 73:1904-1911. doi:10.2136/sssaj2008.033.

[71] Evangelou, M. W. H., Papazoglou, E. G., Robinson, B. H., and Schulin, R. 2015. «Phytomanagement: phytoremediation and the production of biomass for economic revenue on contaminated land,» in Phytoremediation, Management of Environmental Contaminants, Vol. 1, eds A.

[72] Banuelos, G. S., and Dhillon, K. S. 2011. Developing a sustainable phytomanagement strategy for excessive selenium in western United States and India. Int. J. Phytoremediation 13 (Suppl. 1), 208-228.

[73] Mueller J.G., Cerniglia C.E., Pritchard P.H. 1996. Bioremediation of environments contaminated by polycyclic aromatic hydrocarbons. En: Bioremediation: Principles and Applications. Idaho, Estados Unidos. Cambridge University Press.

[74] Mulligan CN, Yong RN. 2004. Natural attenuation of contaminated soils. Environ Int 30:587-601.

[75] Yeung, A. 2010. Remediation Technologies for Contaminated Sites. 10.1007/978-3-642-04460-1_25.

[76] Lee, K., Park, J.W. and Ahn, I. S. 2003. Effect of additional carbon source on naphthalene biodegradation by Pseudomonas putida G7, Jour.l of Hazar. Mat.. 105:157-167.

[77] Abioye, O.P,. 2011. Biological Remediation of Hydrocarbon and Heavy Metals Contaminated Soil, Soil Contamination, Simone Pascucci, IntechOpen. Available from: https://www.intechopen.com/books/soil-contamination/biological-remediation-of-hydrocarbon-and-heavy-metals-contaminated-soil

[78] Mrozik, A., Piotrowska-Seget, Z., 2010. Bioaugmentation as a strategy for cleaning up of soils contaminated with aromatic compounds. Microbiol. Res. $165,363-375$.

[79] Lebeau, T., 2011. Bioaugmentation for in situ soil remediation: how to ensure the success of such a process. Bioaug., Biost. Biocon., pp. 129-186.

[80] Agnello, A.C., Bagard, M., van Hullebusch, E.D., Esposito, G., Huguenot, D., 2016. Comparative bioremediation of heavy metals and petroleum hydrocarbons co-contaminated soil by natural attenuation, phytoremediation, bioaugmentation and bioaugmentation-assisted phytoremediation. Sci. Total Environ. 563-564, 693-703.

[81] Cycoń M., Mrozik A., Piotrowska-Seget Z., 2017. Bioaugmentation as a strategy for the remediation of pesticide-polluted soil: A review. Chemosph., Vol. 172, 52-71.

[82] Chen P, Li J, Wang HY, Zheng RL, Sun GX (2017). Evaluation of bioaugmentation and biostimulation on arsenic remediation in soil through biovolatilization. Environ. Sci. Poll. Res. 24(27): 21739-21749. 
[83] Garbisu, C., González, S., Yang, W.H., Yee, B.C., Carlson, D. E., Yee, A., Smith, N.R., Otero, R., Buchanan, B.B., Leighton, T., 1995 Physiological mechanisms regulating the conversion of selenite to elemental selenium by Bacillus subtilis. BioFactors, 5, 29-37.

[84] Burmølle M, Webb JS, Rao D, Hansen LH, Sørensen SJ, Kjelleberg S. 2006. Enhanced biofilm formation and increased resistance to antimicrobial agents and bacterial invasion are caused by synergistic interactions in multispecies biofilms. App. and Environ. Microbi.. 72(6): 3916-3923.

[85] Kieser T, Bibb MJ, Buttner MJ, Charter KF, Hopwood DA, Centre JI. 2000. Practical Streptomyces Genetics. Norwich, Reino Unido. The John Innes Foundation.

[86] Salles JF, Samyn E, Vandamme P, van Veen JA, van Elsas JD. 2005. Soil Biol Biochem, in press.

[87] Caballero-Mellado J., Onofre-Lemus J., Estrada-de Los Santos P., MartínezAguilar L. 2007. The tomato rhizosphere, an environment rich in nitrogenfixing Burkholderia species with capabilities of interest for agriculture and bioremediation. Appl Environ Microbiol. Aug;73(16):5308-19.

[88] Chain PS, Denef VJ, Konstantinidis KT, Vergez LM, Agulló L, ... Tiedje JM.2006. Burkholderia xenovorans LB400 harbors a multi-replicon, 9.73-Mbp genome shaped for versatility. Proc Natl Acad Sci U S A. Oct 17;103(42):15280-7. doi: 10.1073/pnas.0606924103.

[89] Seeger M, Zielinski M, Timmis KN, Hofer B. 1999. Appl Environ Microbiol 65:3614-3621.

[90] Seeger M, Timmis KN, Hofer B. 1995. Appl Environ Microbiol 61:2654-2658.

[91] Maltseva OV, Tsoi TV, Quensen JF, III, Fukuda M, Tiedje JM.1999. Biodegrad. 10:363-371.

[92] Urtuvia, V., Villegas, P., Fuentes A. Gonzalez, M,. Seeger, M. 2018. Burkholderia xenovorans LB400 possess a functional polyhydroxyalkanoate anabolic pathway encoded by the pha genes and synthesizes poly(3hydroxybutyrate) under nitrogen-limiting conditions. Intern.Microb.. 21. 10.1007/s10123-018-0004-3.

[93] Zhang, H., H. Luo, and Y. Kamagata. 2003. Characterization of the phenol hydroxylase from Burkholderia kururiensis KP23 involved in trichloroethylene degradation by gene cloning and disruption. Microbes Environ. 18:167-173.

[94] Sinha, R.K., Bharambe, G., Ryan, D., 2008. Converting wasteland into wonderlandby earthworms-a low-cost nature's technology for soil remediation: a casestudy of vermiremediation of PAHs contaminated soil. Environm. 28,466-475.

[95] Mohee R., Soobhany N. 2014. Comparison of heavy metals content in compost against vermicompost of organic solid waste: Past and present Resources. Conserv. and Recyc.Vol 92, 206-213.

[96] Sinha, R.K., Agarwal, S., Chauhan, K., Chandran, V., Soni, B.K., 2010. Vermiculture technology: reviving the dreams of Sir Charles Darwin for scienti- 
Erik Urionabarrenetxea, Nerea Garcia-Velasco, Mikel Anza, Unai Artetxe, Rafael Lacalle, Carlos Garbisu, Txema Becerril, Manu Soto

fic use of earthworms in sustainable development programs. Technol. Invest. 1,155172 .

[97] Kavehei A., Hose G.C., Gore D.B. 2018. Effects of red earthworms (Eisenia fetida) on leachability of lead minerals in soil. Environ. Pollut.. Vol 237, 851-857.

[98] Hickman, Z.A., Reid, B.J., 2008. Earthworm assisted bioremediation of organic con-taminants. Environ. Int. 34, 1072-1081.

[99] Kretzshmar A. 2004.In: Edwards CA, editor. Earthworm Ecology. Boca Raton, Florida: CRC Press;. p. 201-10.

[100] Dominguez J. 2004. In: Edwards CA, editor. Earthworm Ecology. Boca Raton, Florida: CRC Press;. p. 401-24.

[101] Shipitalo MJ, Le Bayon RC. 2004. In: Edwards CA, editor. Earthworm Ecology. Boca Raton, Florida: CRC Press;. p. 183-200.

[102] Edwards CA, Bohlen CJ. 1996. Biology and Ecology of Earthworms. 3rd ed. London: Chapman \& Hall.

[103] Farenhorst A, Topp E, Bowman BT, Tomlin AD, Bryan RB. Sorption of atrazine and metolachlor by burrow linings developed in soils with different crop residues at the surface. J Environ Sci Health 2001;B36(4):389-96.

[104] Brown GB, Doube BM. 2004. In: Edwards CA, editor. Earthworm Ecology. Second ed. Boca Raton, Fl: CRC Press;. p. 213-39.

[105] Tejada, M., Masciandaro, G., 2011. Application of organic wastes on a benzo(a)pyrenepolluted soil. Response of soil biochemical properties and role of Eisenia fetida.Ecotox. Environ. Safe. 74, 668-674.

[106] Verma K, Agrawal N, Farooq M, Misra RB, Hans RK. 2006. Endosulfan degradation by a Rhodococcus strain isolated from earthworm gut. Ecotoxicol Environ Saf;64:377-81.

[107] Binet, F., Kersanté, A., Munier-Lamy, C., Le Bayon, R.C., Belgy, M.J., Shipitalo, M.J.,2006. Lumbricid macrofauna alter atrazine mineralization and sorption in a siltloam soil. Soil Biol. Biochem. 38, 1255-1263.

[108] Ma, W.C., Immerzeel, J., Bodt, J., 1995. Earthworms and food interactions on bioaccu-mulation and disappearance in soil of polycyclic aromatic hydrocarbons: studieson phenanthrene and fluoranthene. Ecotox. Environ. Saf. 32, 226-232.

[109] Eijsackers, H., van Gestel, C., De Jonge, S., Muijs, B., Slijkerman, D., 2001. Polycyclicaromatic hydrocarbons-polluted dredged peat sediments and earthworms: a mutual interference. Ecotoxicol. 10, 35-50.

[110] Kersanté, A., Martin-Laurent, F., Soulas, G., Binet, F., 2006. Interactions of earthworms with Atrazine-degrading bacteria in an agricultural soil. FEMS Microbiol. Ecol.57, 192-205.

[111] Contreras-Ramos, S.M., Álvarez-Bernal, D., Dendooven, L., 2008. Removal of poly-cyclic aromatic hydrocarbons from soil amended with biosolid or vermicompostin the presence of earthworms (Eisenia fetida). Soil Biol. Biochem 40, 1954-1959.

[112] Rodriguez-Campos, J., Dendooven, L., Alvarez-Bernal, D., Contreras-Ramos S.M., 2014. Potential of earthworms to accelerate removal of organic contaminants from soil: A review. Appl.Soil Ecol.y 79 (2014) 10-25. 
[113] Rorat, A., Wloka, D., Grobelak A,, Grosser A., Sosnecka, A., Milczarek, M., Jelonek, P.,Vandenbulcke, F., Kacprzak, M., 2017. Vermiremediation of polycyclic aromatic hydrocarbons and heavy metals in sewage sludge composting process. Journ. Environ. Manag. 187 347-353.

[114] Singer AC, Jury W, Leupromchai E, Yahng C-S, Crowley DE. 2001.Contribution of earthworms to PCB bioremediation. Soil Biol Biochem;33:765-75.

[115] Luepromchai E, Singer AC, Yang C-H, Crowley DE. 2002. Interactions of earthworms with indigenous and bioaugmented PCB-degrading bacteria. FEMS Microbiol Ecol;41:191-7.

[116] Goswami, L., Sarkar, S., Mukherjee, S., Das, S., Barman, S., Raul, P., Bhattacharyya, P., Mandal, N.C., Bhattacharya, S., Bhattacharya, S.S., 2014. Vermicomposting of tea factory coal ash: metal accumulation and metallothionein response in Eisenia fetida (Savigny) and Lampito mauritii (Kinberg). Bioresour. Technol. 166, 96-102.

[117] Suthar S., Sajwan, P.,Kumar Kapil.,2014. Vermiremediation of heavy metals in wastewáter sludge from paper and pulp industry using earthworm Eisenia fetida. Ecotox. Environ. Saf. 109(2014)177-184.

[118] Sahariah, B., Goswami, L., Kim K.H, Bhattacharya, S.S.,2015. Metal remediation and biodegradation potential of earthworm species on municipal solid waste: A parallel analysis between Metaphire posthuma and Eisenia fetida. BioresourTechnoly 180 230-236.

[119] Nouha, K., Kumar, R.S., Tyagi, R.D., 2016. Heavy metals removal from wastewater using extracellular polymeric substances produced by Cloacibacterium normanense in wastewater sludge supplemented with crude glycerol and study of extracellular polymeric substances extraction by different methods. Bioresour. Technol. 212, 120-129.

[120] Dong, Z.-Y., Huang, W.-H., Xing, D.-F., Zhang, H.-F., 2013. Remediation of soil cocontaminated with petroleum and heavy metals by the integration of electrokinetics and biostimulation. J. Hazard Mater. 260, 399-408.

[121] Biswas, B., Sarkar, B., Mandal, A., and Naidu, R. (2015) Heavy metalimmobilizing organoclay facilitates polycyclic aromatic hydrocarbon biodegradation in mixed-contaminated soil.J Hazard Mater.298:.129-137.

[122] Joner E. J. \& Leyval C. 2001. «Time-course of heavy metal uptake in maize and clover as affected by root density and different mycorhizal inoculation regimes,» Biol. Fertil.y of Soils,. 33, 5, 351.357.

[123] Jamal A., Ayub N., Usman M., Khan A. G. 2002. «Arbuscular mycorrhizal fungi enhance zinc and nickel uptake from contaminated soil by soybean and lentil". Intern. Jour. of Phytorem, 4, 3,205-221.

[124] Weyens N., Van Der Lelie D., Artois T., ... Vangronsveld J.2009. Bioaugmentation with engineered endophytic bacteria improves contaminant fate in phytoremediation. Environ Sci Technol 43: 9413-9418.

[125] Glick B. R., Karaturovic D. M., Newell P. C. 1995. «A novel procedure for rapid isolation of plant growth promoting pseudomonads,» Canadian Jour. Microb, vol. 41, 6, 533-536. 
[126] Kamnev A. A. \& van der Lelie D. 2000. «Chemical and biological parameters as tools to evaluate and improve heavy metal phytoremediation,» Bioscie. Rep.,. 20, 4, 239-258.

[127] Khan A.G. 2005. "Role of soil microbes in the rhizospheres of plants growing on trace metal contaminated soils in phytoremediation,» Journ. Trace Eleme.s Medic. and Biol., vol. 18, 4, 355-36.

[128] Glick B.R., Penrose D.M., Li J. 1998. «A model for the lowering of plant ethylene concentrations by plant growth-promoting bacteria,» Journal of Theoretical Biology, vol. 190, 1, 63-68.

[129] Drake, H.L., Horn, M.A., 2007. As the worm turns: the earthworm gut as a transient habitat for soil microbial biomes. Annu. Rev. Microbiol. 61, 169-189.

[130] Hong, S.W., Kim, I.S., Lee, J.S., Chung, K.S., 2011. Culture-based and denaturing gra-dient gel electrophoresis analysis of the bacterial community structure from the intestinal tracts of earthworms (Eisenia fetida). J. Microbiol. Biotechnol. 21,885-892.

[131] Tiquia, S.M., 2010. Salt-adapted bacteria isolated from the Rouge River and poten-tial for degradation of contaminants and biotechnological applications. Environ.Technol. 31, 967-978.

[132] Wu, X., Monchy, S., Taghavi, S., Zhu, W., Ramos, J., van der Lelie, D., 2011.Comparative genomics and functional analysis of niche-specific adaptation in Pseudomonas putida. FEMS Microbiol. Rev. 35, 299-323.

[133] Yee, D.C., Wood, T.K., 1997. 2,4-Dichlorophenol degradation using Streptomyces viri-dosporus T7A lignin peroxidase. Biotechnol. Progr. 13, 53-59.

[134] Khalid, A., Arshad, M., Crowley, D.E., 2008. Decolorization of azo dyes by Shewanellasp under saline conditions. Appl. Microbiol. Biot. 79, 1053-1059.

[135] Urionabarrenetxea E., Garcia-Velasco N., Anza M., Artetxe U., Lacalle R., Garbisu C., Becerril T., Soto M. 2021. Application of in situ bioremediation strategies in soils amended with sewage sludges. Sci. of total Environ. 766.144099 . 